\section{EREM 75/1}

Journal of Environmental Research, Engineering and Management Vol. 75 / No. 1 / 2019 pp. $24-33$

DOI 10.5755/j01.erem.75.1.21121
Zoogenic Mechanisms of Ecological Rehabilitation of Urban Soils of the Park Zone of Megapolis: Earthworms and Soil Buffer Capacity

\title{
Zoogenic Mechanisms of Ecological Rehabilitation of Urban Soils of the Park Zone of Megapolis: Earthworms and Soil Buffer Capacity
}

\section{Oleh Didur, Yurii Kulbachko}

Oles Honchar Dnipro National University, Gagarin ave., 72, Dnipro, 49010, Ukraine

\section{Yuliia Ovchynnykova}

Vasyl' Stus Donetsk National University, 600-richcha str., 21, Vinnytsia, 21021, Ukraine

\section{Alevtyna Pokhylenko, Tatyana Lykholat}

Oles Honchar Dnipro National University, Gagarin ave., 72, Dnipro, 49010, Ukraine

\section{Corresponding authors: didur@ua.fm}

Oleh Didur, Oles Honchar Dnipro National University, Gagarin ave., 72, Dnipro, 49010, Ukraine

Earthworms (Oligochaeta: Lumbricidae) are typical representatives of the functional group of ecosystem engineers. They actively participate in formation and stabilisation of soil fertility through their effect on its buffer capacity. Buffer capacity defines in many aspects soil potential, supports immobilisation and mobilisation of certain elements of fertility, and first of all mineral elements essential for plants, productive moisture, heat energy of soil, gas composition of soil air, etc. Park soils within megapolises territory are megapolises' integral components, and this feature defines conditions of growth and development for green plants. To evaluate the contribution of earthworm coprolites into acidic-base $(\mathrm{pH})$ buffer capacity of two categories of soil within the city, i.e., urban soils and urban grounds (urbanozems) of the park zones within the plots planted with Norway maple (Acer platanoides L.) trees on the territory of two parks Zeleny Gai and Pisarzhevsky Park (city 
Dnipro, Ukraine), soil and coprolites samples were collected. Buffer capacity of coprolites and anthropogenically transformed soils (urban soils) was evaluated according to the Arrhenius method after "a buffer area". It was established that acid-base buffer capacity of coprolites (earthworm excretes), which are new formations of zoogenic origin in soil, was statistically significantly higher than for the initial type soil within city parks. For urban soil with the upper humified layer of calcic chernozem within the acidic diapason of external load, it was $22.9 \%$ higher, which, on average, accordingly was 22.9 and 18.7 convectional units; within alkaline, it was $18.4 \%$ higher and was, accordingly, 24.2 and 20.4 convectional units; and in sum (acidic-alkaline), it was $20.6 \%$ higher and was 47.1 and 39.1 convectional units. For urban ground (urbanozem) within the acidic diapason of external load, it was $44.9 \%$ higher and acidic-alkaline buffering capacity, on average, accordingly, was 25.5 and 17.6 convectional units; in sum (acidic-alkaline), it was $20.6 \%$ higher and was 42.8 and 35.4 convectional units, accordingly. Thus, soil saprophages, such as earthworms, in the conditions of magapolises in the recreation zones within the territories of city parks' green plantations are one of the natural factors of ecological rehabilitation of urban soils. This, in general, improves the ecological state of green plantations on urban soils within park areas and recreation zone edaphotope revitalisation as well as supports optimisation of human living and recreation environment.

Keywords: pertinent function of saprophages, urban soil, buffer capacity of soil, fertile elements potential, city park.

\section{Introduction}

Healthy and fertile soil is national property, although within city territory, soil ceases to be as historical naturally and organic-mineral body. Natural undisturbed soils are left only as islands in city parks and forest parks. In a large part of megapolises, specific soil-like bodies - urban soils and urban grounds (urbanozems) that are different from natural soils in their structure, properties and functions - are formed (Mirzak, 2001; Tyutyunnik, 2014; Khokhryakova, 2016; Novosyolova et al., 2017).

The environmental negative consequences, which soil tolerates within urbanised territories, include such signs of physical and chemical degradation as soil profile disturbance, densification of the root layer, which put limits for root system development for plants, nutrients, humus and trace element depletion, heavy metal and other toxicant contamination, change in acidity and alkalinity, reduction of the diversity of soil microflora and soil invertebrates, accumulation of industrial and urban dust (Gavryushova, 2013; Ferrini et al., 2014; Agapkina et al., 2015; Łukasik et al., 2015; Pavlović et al., 2017, etc.).

Parks are a necessary part of the urban area. They participate in the formation of urban architectural appearance and are an important component of any modern metropolis. However, the coexistence of the urban system and greenery is becoming increasingly strained (Sieghardt et al., 2005; Zavaltseva et al., 2014). Soil is an integral component of park zones in urban areas that determines the conditions for the growth and development of green plants in megapolises and fulfils important ecological functions (Ecology of the city, 2000, 2008; Li et al., 2008; Morel et al., 2015). Considering the above, the main function of the soil is the ability to provide plants with nutrition, water, and provide air and heat for plants' root system and create favourable physico-chemical environment for normal growth and development (fertility), as well as the ability to absorb pollutants in and to retain them from penetration into groundwater (buffer capacity relative to heavy metals), which is important in the manifestation of human health potential (Lykholat et al., 2016).

The main element of any park of a megacity is green plantations. They, as part of the urban landscape, soften and ennoble urban buildings, and have great sanitary, hygienic, recreational, landscape-architectural and aesthetic significance (Tyrväinen et al., 2005; Annerstedt et al., 2012; Bertram \& Rehdanz, 2015; Breuste \& Rahimi, 2015). As these sites are resting 
places and always exist under difficult environmental conditions, they are constantly under the influence of increased recreational and anthropogenic load and gradually lose their functional and structural stability. One of the manifestations is the intensification of invasions of some adventive tree and grass species in parks within the territory of urban ecosystems (Lykholat et al., 2017). Therefore, for the territory of megapolises, especially for their park areas, there is always an urgent need to create conditions for the restoration and optimisation of both the ecological properties of soils and tree plantations in general.

Animals - ecosystem engineers - play an important role among others in improving the ecological properties of soil (Eisenhauer, 2010; Grimaldi et al., 2016; Didur et al., 2018). The formation of the soil structure and the main biochemical soil process - humification - and ultimately the vitalisation and naturalisation of edaphotopes is the result of their pedoturbation and trophic activity.

Ecosystem engineers influence the rate of decomposition of dead plant residues through their fragmentation and subsequent dispersion in the terrestrial ecosystem (Sjursen et al., 2005), and, therefore, the rate of matter turnover and the release of ash chemical elements. These are, first of all, such representatives of the mesofauna as typical saprophages, e.g., earthworms (Lavelle et al., 2007; Berke, 2010; Kitz et al., 2015), two-legged centipedes (Gudym, 2016), lice (Striganova, 1980; Toth et al. , 2016), as well as particular representatives of the microfauna like oribatid mites (Smrž, 2004; Gormsen et al., 2006). Their activity is mainly connected to the provision of such ecosystem services as increasing soil fertility and participation in nutrient turnover. Benefits received from such services are not only limited to a soil ecosystem; green plantations also benefit from activity of these groups, which determine their significance. The value of these services is significantly increasing for recreation areas of modern megapolises under current conditions of climate change (Stott, 2017) with increasing aridity and temperature (Klymenko et al., 2017), especially in semiarid climatic zones.

Due to the tropho-metabolic activity of earthworms, coprolites can be found both on the soil surface and within soil layers. They are a mixture of a mineral substrate enriched with carbon, nitrogen-enriched and organic matter and, in comparison with initial soils, have increased water resistance, water capacity and relative resistance to mechanical action (Tomlin et al., 1995; Schrader \& Zhang, 1997; Shipitalo \& Le Bayon, 2004). An additional mechanism, in which earthworms (Oligochaeta: Lumbricidae) affect the elements of fertility, is the formation and stabilisation of soil aggregates. The soil that was swallowed by worms and passed through their intestines acquires a grainy structure that is stable and resistant to water erosion. This structure determines the agronomic value of such soil (Albrecht, 1998; Riley et al., 2008; Lemtiri et al., 2014) and, consequently, creates physical conditions that promote the development of plant root systems and the assimilation of elements of mineral nutrition. Thus, earthworms structure up the soil, make it airtight, enriched with nutrients and, ultimately, fertile under favourable conditions. Charles Darwin was one of the first naturalists who at the end of the $19^{\text {th }}$ century pointed out the importance of earthworms in the process of soil formation.

Consequently, the assessment of the degree of influence of earthworms on ecosystem components and, in particular, the influence of trophy-metabolic activity of earthworms on the buffering capacity of soils within recreational zones on the territory of megapolises, for example, urban parks, is of scientific and practical interest.

The aim of the study was to determine the contribution of soil new formations of zoogenic origin (coprolites of earthworms) into the buffering capacity of two categories of urban soils - urban and urban grounds within plots of Norway maple leaf in the park zone on the territory of Dnipro (Ukraine).

In a broad sense, the buffer capacity of the soil characterises its energy potential, which determines the mobilisation (release) and immobilisation (deposition) of fertility elements (Truskavetskii, 2003). Buffering is more often interpreted as the ability of the soil to resist the changes in its actual reaction under the influence of various factors. This is the so-called acid-base buffering or pH buffering (Truskavetskii, 2003; Kissel et al., 2012). Different soils have different buffering, for example, sandy soils and podzolic soils have significantly lower buffering compared with clay and 
loamy soils or soils enriched with organic matter (van Rensburg et al., 2009; Murphy, 2015). Scientific publications are mostly devoted to the studies of the buffer capacity of soils in the agricultural field (Truskavetskii, 2003; Hamkalo, 2004; Huang et al., 2009), or they are devoted to studying the buffer capacity of various genetic types of soils (Mowbray \& Schlesinger, 1988; Raczuk \& Deska, 2012). There is absolutely no information on the participation of soil saprophages in the formation and maintenance of buffer properties of urban soils under tree plantations in recreational zones, because the buffer mechanisms of the soil were considered by researchers only in the system "external influences - soil - plant". The role of animals which are ecosystem engineers in stabilising soil fertility and its elementary components in anthropogenically changed territories, in particular, in the megalopolis, and in changing the buffer capacity of soils, remained without attention.

\section{Materials and Methods}

\section{Data collection}

Field material was sampled during 2016 and 2017 in areas planted with Norway maple (Acer platanoides L.) within territories of Zeleny Gai Park and Pisarzhevsky Park (Dnipro, Ukraine). The city of Dnipro is a large industrial centre. It is located in the geographical steppe zone, which covers $40 \%$ of the total territory of Ukraine (Brygadyrenko, 2015).

Geomorphologically Zeleny Gai Park is located within the flat interfluve-terrain type of the landscapes of the right bank of the river Dniper and covers one of the city terrains (the Rybalska Balka). The total area of the park is 40 hectares. The soil cover of the park is classified as anthropogenically superficially transformed soils - urban soils (according to Stroganova et al., 1998), which partially retained its natural structure. The soils of the park are potentially suitable for the growth of woody and shrubby vegetation. In 2017 , partial reconstruction of the park was started.

The Pisarzhevsky Park is located within the flat interfluve-terrain type of the landscapes of the right bank of the river Dniper, on the watershed between two terrains (Rybalskaya and Krasnopovstanskaya). The total area of the park is 7.9 hectares. The area planted with the greens is 7 hectares. The soil cover of the park is categorised as deeply transformed soils - urban ground (urbanozem) (according to Stroganova et al., 1998). The soils of the park are potentially suitable for the growth of woody and shrubby vegetation. Pisarzhevsky Park in relation to Zeleny Gai Park is shifted in the southeast direction and adjacent to it at the nearest distance by $160 \mathrm{~m}$ and at remote by $750 \mathrm{~m}$.

To determine the effect of the excretory activity of saprophages by the example of earthworms (Lumbricidae) on the $\mathrm{pH}$-buffering capacity of soils within the park zones, samples of soil and coprolites were collected. Soil samples from the top layer of $0-10 \mathrm{~cm}$ were collected along with fresh coprolites of earthworms collected from the soil surface within the plantations of Norway maple (Acer platanoides L.) of the studied park zone.

\section{Data analysis procedure}

Determination of the acid-base buffering of soils and new zoogenic formations (coprolites of earthworms) is based on establishing changes in the $\mathrm{pH}$ value after addition of aliquots of weak solutions of acids or alkalis (Nelson \& Su, 2010). To determine the buffer capacity of coprolites and park soils, the method of titration curves, in particular the Arrhenius method (Truskavetskii, 1980; Raczuk \& Deska, 2012), was applied.

The titration curves were established by appropriate addition of a series of volumes of standardised hydrochloric acid $\left(\mathrm{HCl}, 0.1 \mathrm{~mol} / \mathrm{dm}^{3}\right)$ and sodium hydroxide $\left(\mathrm{NaOH}, 0.1 \mathrm{~mol} / \mathrm{dm}^{3}\right)$ (Huang et al., 2009) to soil and coprolites, previously suspended in deionised water. The total amount of solution, i.e., water and acid or water and alkali, was constant. The same procedure was carried out for the buffer-free substrate - pure calcined sand. The $\mathrm{pH}$ values of the solutions were measured after resuspension of the samples during 1 hour.

According to the results of measurements of the actual values, graphs were plotted with the abscissa indicating the number of millilitres of the added acid (or alkaline) component and the ordinate indicating the corresponding $\mathrm{pH}$ values. Obtained curves allow 
estimating the buffering of the investigated soils and soil excrements (coprolites) according to the "buffering area" within the region of the acid and alkaline intervals of the external effect. It was determined as the area between the titration curve of the prototype and the no-buffer standard and expressed in conventional square centimetres. The numerical integration method was used to calculate buffer areas. The task was solved using the Simpson formula (Atkinson, 1989; Chapra, 2012).

The changes in actual acidity of the soil solutions $(\mathrm{pH})$ of the buffer-free substrate and test samples were measured in triplicate. The experimental data were statistically processed. The arithmetic mean, its standard error, the significant difference in the averages according to the two-sided Student $t$ criterion were calculated.

\section{Results and Discussion}

In the result of their vital activity, earthworms contribute significantly to the transformation of soil characteristics and properties (Aira et al., 2003; Bottinelli et al., 2010; Choosai et al., 2010; Blouin et al., 2013). This biotic effect is important during the naturalisation of transformed soils and the stability of parkland tree plantations within the territory of megalopolises.

The effect of earthworm coprolites on the buffering capacity of urban soil (Zeleny Gai Park). The buffer curves in the acidic (Fig. 1) and alkaline (Fig. 2) ranges for urban soil (upper humified layer), soil formations of zoogenic origin (coprolites of earthworms),
Fig. 1

Buffering curves (acid interval) for samples of urban soils (upper humus layer) and coprolites of earthworms collected from the territory of Zeleny Gai Park and the buffer-free substrate

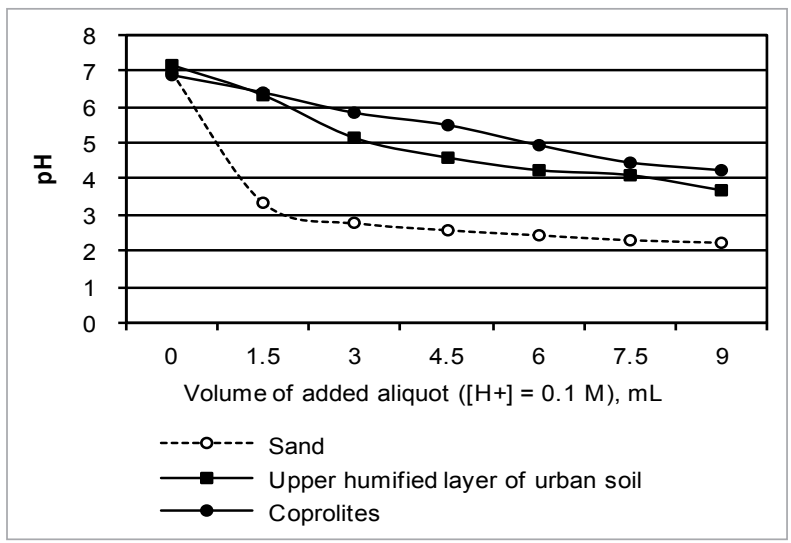

Fig. 2

Buffering curves (alkaline interval) for samples of urban soils (upper humus layer) and coprolites of earthworms collected from the territory of Zeleny Gai Park and the buffer-free substrate

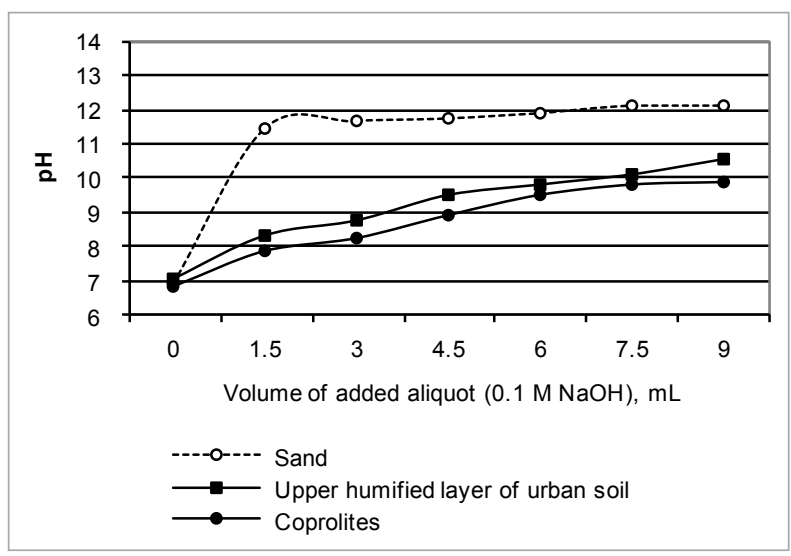

\section{Table 1}

Assessment of the buffer capacity of the upper humified layer of urban soil and new soil formations (coprolites of earthworms) within the plantation of Norway maple in the territory of the city park Zeleny Gai

\begin{tabular}{l|c|c|c|c}
\hline \multirow{2}{*}{ Interval of external effect } & \multicolumn{2}{|c|}{$\begin{array}{c}\text { Average buffering area } \\
\text { and standard error, } \mathrm{cm}^{2}\end{array}$} & $\begin{array}{c}\text { Level of significance of } \\
\text { difference between averages } \\
\text { according to Student } t \text { criteria }\end{array}$ & $\begin{array}{c}\text { Contribution of coprolites } \\
\text { into the buffering } \\
\text { capacity (\%) }\end{array}$ \\
\cline { 2 - 5 } & Urban soil & Coprolites & 4 & 5 \\
\hline Acidic & 2 & 3 & 0.0007 & 22.9 \\
\hline Alkaline & $18.66 \pm 0.094$ & $22.94 \pm 0.441$ & 0.006 & 18.4 \\
\hline Acidic-alkaline (total) & $20.41 \pm 0.475$ & $24.17 \pm 0.525$ & 0.0014 & 20.6 \\
\hline
\end{tabular}


collected on the territory of the city park Zeleny Gai within the Norway maple plantation and the buffer-free substrate were visualised. The location of the titration curves of the studied samples in these ranges of chemical action indicates that the buffer area of the earthworm coprolites is greater than the buffer area of the upper humified layer of the investigated soil samples collected within tree plantation.

The total buffer area of coprolites is statistically significantly greater than the total buffer area of the upper humified layer of the urban soil. In this case, practically close in magnitude contribution is achieved for both due to the buffering of coprolites in the acidic and alkaline intervals (Table 1).

\section{The effect of earthworm coprolites in the buffering capacity of urban ground (urbanozem) (Pisarzhevsky}

Park). Buffer curves are visualised on the graph in the acidic (Fig. 3) and alkaline (Fig. 4) ranges for urban soil (upper humified layer) and soil formations of zoogenic origin (coprolites of earthworms), collected on the territory of the Pisarzhevsky Park (Dnipro city) within the Norway maple plantation for the buffer-free substrate. The location of the titration curves of the studied samples in these ranges of chemical action indicates that the buffer area of earthworm coprolites is greater than the buffer area of the upper humified layer of the studied soil collected within tree plantation.

The total buffer area of coprolites is statistically significantly greater than the total buffer area of the upper humified layer of the urban soil. At the same time, a strong contribution is achieved due to the buffer capacity of coprolites in the acid range. In the alkaline range, this contribution is insignificant and inferior to the buffer capacity of the investigated urban soil samples (Table 2).
Fig. 3

Buffering curves (acid interval) for samples of urbanozem (upper humus layer) and coprolites of earthworms collected from the territory of Pisarzhevsky Park

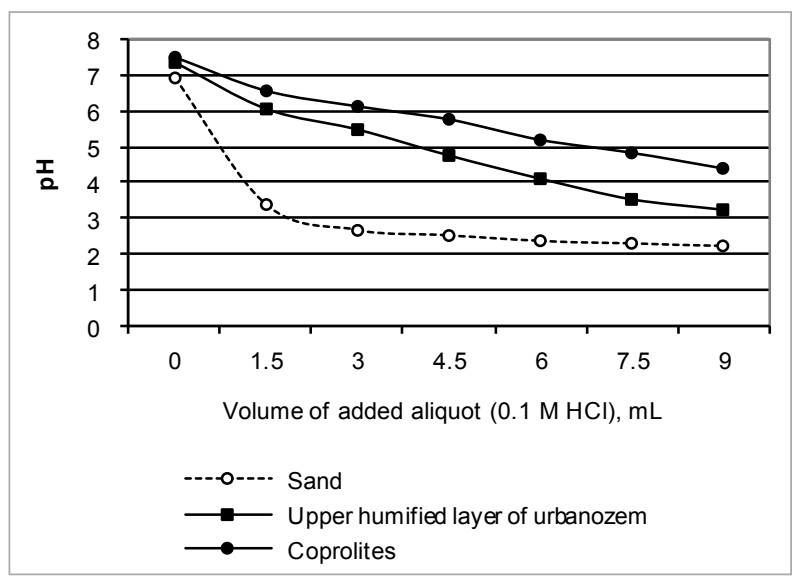

Fig. 4

Buffering curves (alkaline interval) for samples of urbanozem (upper humus layer) and coprolites of earthworms collected from the territory of Pisarzhevsky Par

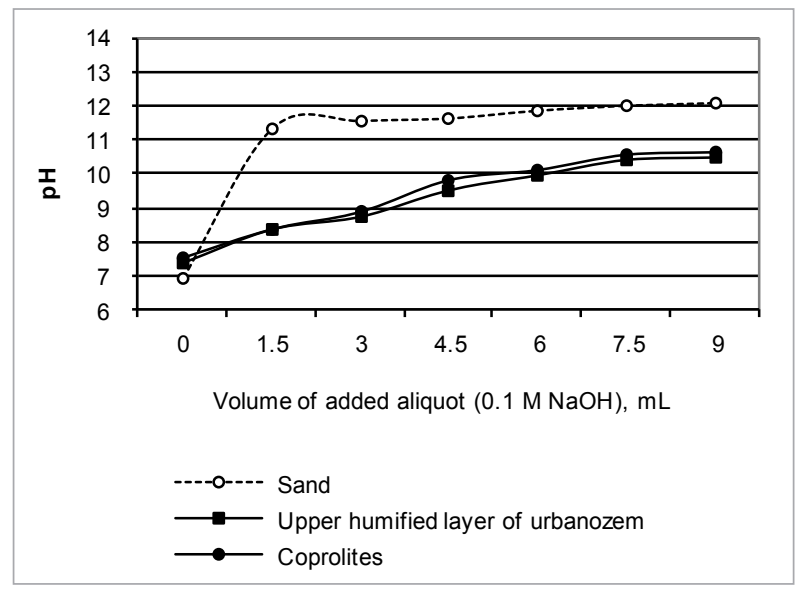

\section{Table 2}

Assessment of the buffer capacity of the upper humified layer of urban ground (urbanozem) and new soil formations (coprolites of earthworms) within the plantation of Norway maple in the territory of Pisarzhevsky Park

\begin{tabular}{l|c|c|c|c}
\hline \multirow{2}{*}{ Interval of external effect } & \multicolumn{2}{|c|}{$\begin{array}{c}\text { Average buffering area } \\
\text { and standard error, } \mathrm{cm}^{2}\end{array}$} & $\begin{array}{c}\text { Level of significance of } \\
\text { difference between averages } \\
\text { according to Student } t \text { criteria }\end{array}$ & $\begin{array}{c}\text { Contribution of } \\
\text { coprolites into the } \\
\text { buffering capacity (\%) }\end{array}$ \\
\cline { 2 - 5 } & Urbanozem & Coprolites & 4 & 5 \\
\hline Acidic & 2 & 3 & 0.00009 & 44.9 \\
\hline Alkaline & $17.58 \pm 0.185$ & $25.48 \pm 0.453$ & 0.033 & -8.22 \\
\hline Acidic-Alkaline (total) & $18.86 \pm 0.4067$ & $17.31 \pm 0.2658$ & 0.000036 & 17.43 \\
\hline
\end{tabular}


It should be noted that the state of the soil cover of the green areas of the megapolis, in particular within city parks, is of great importance for the sustainable functioning of the vegetation cover and the urban environment as a whole. One of the natural mechanisms that positively affects optimisation of anthropotechnologically-disturbed soils, including urban parks, is the medium-transforming activity of earthworms as typical representatives of the functional group of ecosystem engineers. Pedoturbation and trophometabolic (excretory) functions of earthworms are essential factors of soil fertility. Among the properties of the soil, the buffering determines the processes of depositing or releasing elements of fertility (especially such as chemical elements of mineral nutrition, productive moisture, and heat). Since representatives of earthworms significantly affect the trophic, moisture, aerial, aggregative, sanitary-detoxic and productive functions of the soil, their activity determines the buffer capacity for each certain element of fertility. The results of the research indicated that, in general, the acid-base buffer capacity of new soil formations of zoogenic origin - coprolites (excreta) of earthworms - was by $20.6 \%$ and $17.4 \%$ higher than the initial transformed soil of park territories (respectively, Zeleny Gai Park and Pisarzhevsky Park), and their average $\mathrm{pH}$ buffers had statistically significant differences with high levels of significance.

The contribution of coprolites to the $\mathrm{pH}$ buffer capacity in the acid range was by $22.9 \%$ and $44.9 \%$ higher than the buffer capacity of the initial transformed soil (respectively, Zeleny Gai Park and Pisarzhevsky Park). Thus, the trophometabolic activity of such representatives of the saprotrophic block of the zoocenosis as earthworms (Lumbricidae) within the Norway maple plantation in the park zone in the megapolis influences the main component of terrestrial ecosystems, i.e., soil, and its buffer capacity, which determines the fertility potential and is the basis of soil stability.

\section{References}

Agapkina G.I., Brodskiy E.S., Shelepchikov A.A. \& Feshin D.B. (2015). Priority organic pollutants in soil of arboretum of the Botanical Garden of Moscow State University: Report 3. Specific features of vertical distribution pattern of organochlorine pesticide in profile of urbanozem. Moscow University

\section{Conclusions}

While studying the ecological impact of trophometabolic activity of saprophages in urban areas and urban soils in plantations of Norway maple within the territory of two urban parks - Zeleny Gai and Pisarzhevsky Park in the megalopolis (Dnipro), it was established that zoogenic soil formations (coprolites of earthworms) buffer properties of soils. The results of our experiment indicate that the acid-base buffer capacity of coprolites of Lumbricidae representatives is statistically significantly higher than that of the original park soil in the acid range, by $22.9 \%$ and $44.9 \%$ in Zeleny Gai Park and Pisarzhevsky Park, respectively, and in the total (acid-base) ratio by $20.6 \%$ and $17.4 \%$ in Zeleny Gai Park and Pisarzhevsky Park, respectively.

Such permanent function of earthworms within the recreation territory in the park zone of Dnipro megapolis promotes positive changes in the ecological state of soils and naturalisation of edaphotopes of green plantations. Thus, the efficiency of restoring park soils while enriching them with coprolites of earthworms is growing, their ecological quality is improving, breaking of negative influences is observed in conditions of anthropotechnology in the metropolitan area, and trophometabolic (together with pedoturbation) activity of these animals is a powerful factor of ecological rehabilitation of park soils in the territory of metropolis.

\section{Acknowledgements}

This study was performed in the scope of the scientific project "Ecological foundations of animal zoopertinent effects on optimization native and transformed ecosystem processes in the context of current environmental management" (registration number 0117U001207) financed by Ministry of Education and Science of Ukraine.

Soil Science Bulletin 70(4): 180-186. https://doi.org/10.3103/ S014768741504002X

Aira M., Lazcano C., Gómez-Brandón M. \& Domínguez J. (2010). Ageing effects of casts of Aporrectodea caliginosa on soil microbial community structure and activity. Applied Soil Ecology 
46(1): 143-146. https://doi.org/10.1016/j.apsoil.2010.06.001

Albrecht A., Angers D.A., Beare M.H. \& Blanchart E. (1998). Soil aggregation, soil organic matter and soil biota interactions: implications for soil fertility recapitalization in the tropics. Cahiers Agricultures 7(5): 357-363. (In French).

Annerstedt M., Östergren P.O., Björk J., Grahn P., Skärbäck E. \& Währborg G. (2012). Green qualities in the neighbourhood and mental health: results from a longitudinal cohort study in Southern Sweden. BMC Public Health 12: 337. https://doi. org/10.1186/1471-2458-12-337

Atkinson K.E. (1989). An Introduction to Numerical Analysis (2nd ed.). Wiley, New York, $712 \mathrm{p}$

Berke S.K. (2010). Functional groups of ecosystem engineers: a proposed classification with comments on current issues. Integrative and Comparative Biology 50(2): 147-157. https://doi. org/10.1093/icb/icq077

Bertram C. \& Rehdanz K. (2015). The role of urban green space for human well-being. Ecological Economics 120: 139-152. https://doi.org/10.1016/j.ecolecon.2015.10.013

Blouin M., Hodson M.E., Delgado E.A., Baker G., Brussaard L., Butt K.R., Dai J., Dendooven L., Peres G., Tondoh J.E., Cluzeau D. \& Brun J.-J. (2013). A review of earthworm impact on soil function and ecosystem services. European Journal of Soil Science 64(2): 161-182. https://doi.org/10.1111/ejss.12025

Bottinelli N., Henry-des-Tureaux T., Hallaire V., Mathieu J., Benard Y., Duc Tran T. \& Jouquet P. (2010). Earthworms accelerate soil porosity turnover under watering conditions. Geoderma, 156(1-2): 43-47. https://doi.org/10.1016/j.geoderma.2010.01.006

Breuste J. \& Rahimi A. (2015). Many public urban parks, but who profits from them? The example of Tabriz, Iran. Ecological Processes 4(1): 6. https://doi.org/10.1186/s13717-014-0027-4

Brygadyrenko V.V. (2015). Community structure of litter invertebrates of forest belt ecosystems in the Ukrainian Steppe Zone. International Journal of Environmental Research 9(4): 11831192. doi: 10.22059/IJER.2015.1008

Chapra S.C. (2012). Applied numerical methods with MATLAB ${ }^{\circledR}$ for engineers and scientists. 3rd ed. McGraw-Hill, New York, 653 p.

Choosai C., Jouquet P., Hanboonsong Y. \& Hartmann C. (2010). Effects of earthworms on soil properties and rice production in the rainfed paddy fields of Northeast Thailand. Applied Soil Ecology 45(3): 298-303. https://doi.org/10.1016/j.apsoil.2010.05.006

Didur O., Kulbachko Y. \& Maltsev Y. (2018). Impact of tropho-metabolic activity of earthworms (Lumbricidae) on distribution of soil algae within Acer platanoides L. plantation in recultivated territories of Western Donbass (Ukraine) / O. Didur, // Ukrainian Journal of Ecology 8(2): 18-23. doi: 10.15421/2018_304
Didur 0.0., Kulbachko Yu.L. \& Pakhomov O.Ye. (2018). Species Structure of Oribatid Mite Population (Acari, Oribatea) in the Forest Floor Litter in the Reclaimed Territories (Ukraine). Vestnik Zoologii 52(4): 331-340. https://doi.org/10.2478/vzoo-2018-0035

Ecology of the city (2000). Edited by Stolberg F.V. Libra, Kyiv, 464 p. (In Russian).

Ecology of the city (2008). Edited by Denisov V. V. Publishing book center "MarT", Rostov-na-Donu, 832 p. (In Russian).

Eisenhauer N. (2010). The action of an animal ecosystem engineer: Identification of the main mechanisms of earthworm impacts on soil microarthropods. Pedobiologia 53(6): 343-352. https://doi.org/10.1016/j.pedobi.2010.04.003

Ferrini F., Bussotti F., Tattini M. \& Fini A. (2014). Trees in the urban environment: Response mechanisms and benefits for the ecosystem should guide plant selection for future plantings. Agrochimica 58(3): 234-246. doi: 10.12871/0021857201432

Gavryushova O.E. (2013). Environmental aspects of the urban soils transformation under artificial surface. Liudyna ta dovkillia. Problemy neoekolohii 3-4: 164-167. (In Ukrainian).

Gormsen D., Hedlund K. \& Huifu W. (2006). Diversity of soil mite communities when managing plant communities on set-aside arable land. Applied Soil Ecology 31(1-2): 147-158. https://doi. org/10.1016/j.apsoil.2005.03.001

Grimaldi M., Jiménez J.J., McKey D., Mathieu J., Velasquez E. \& Zangerlé A. (2016). Ecosystem Engineers in a self-organized soil: A review of concepts and future research questions. Soil Science 181(3/4): 91-109. https://doi.org/10.1097/ SS.0000000000000155

Gudym N.G. (2016). Seasonal population dynamics of Brachyiulus jawlowskii (Diplopoda, Julidae) in the Dnieper river arena. Visnyk of Dnipropetrovsk University. Biology, ecology 24(2): 489-494. (In Ukrainian). https://doi.org/10.15421/011666

Hamkalo Z. (2004). Differential acid-base buffering of soil as yardstick of ecological efficiency of an organic component of fertilizings of agrophytocenosises. Gruntoznavstvo 5(3-4): 43-46.

Huang P., Zhang J.-bao, Zhu A.-ning \& Zhang C.-zhi (2009). Acid and alkali buffer capacity of typical fluvor-aquic soil in HuangHuai-Hai Plain. Agricultural Sciences in China 8(11): 1378-1383. https://doi.org/10.1016/S1671-2927(08)60350-8

Khokhryakova A.I. (2016). Soils of the cities: features of genesis, classification, diagnostics. Odesa National University Herald. Geography and Geology 21(1): 110-125. (In Ukrainian).

Kissel D.E., Sonon L.S. \& Cabrera M.L. (2012). Rapid Measurement of Soil pH Buffering Capacity. Soil Science Society of America Journal 76(2): 694-699. https://doi.org/10.2136/sssaj2011.0091

Kitz F., Steinwandter M., Traugott M. \& Seeber J. (2015). Increased decomposer diversity accelerates and potentially 
stabilises litter decomposition. Soil biology \& biochemistry 82 : 138-141. https://doi.org/10.1016/j.soilbio.2015.01.026

Klymenko G., Kovalenko I., Lykholat Y., Khromykh N., Didur 0. \& Alekseeva A. (2017). The integral assessment of the rare plant populations. Ukrainian Journal of Ecology 7(2): 201-209. https://doi.org/10.15421/2017_37

Lavelle P., Barot S., Blouin M., Decaëns M.T., Jimenez J.J. \& Jouquet P. (2007). Earthworms as key actors in self-organized soil systems. In: Cuddington K., Byers J., Wilson W., Hastings A. (eds) Ecosystem engineers: Plants to protists. - Academic Press, Burlington (MA), pp 77-106.https://doi.org/10.1016/ S1875-306X(07)80007-4

Lemtiri A., Colinet G., Alabi T., Cluzeau D., Zirbes L., Haubruge É. \& Francis F. (2014). Impacts of earthworms on soil components and dynamics. A review. Biotechnology, Agronomy, Society and Environment 18(1): 121-133.

Li X-hong, Wang W, Wang J, Cao Xue-li, Wang X-fei, Liu J-chang, Liu X-fen, Xu X-bai \& Jiang X-ning (2008). Contamination of soils with organochlorine pesticides in urban parks in Beijing, China. Chemosphere 70(9): 1660-1668. https://doi. org/10.1016/j.chemosphere.2007.07.078

Łukasik A., Szuszkiewicz M.\& Magiera, T. (2015). Impact of artifacts on topsoil magnetic susceptibility enhancement in urban parks of the Upper Silesian conurbation datasets. Journal of Soils and Sediments 15(8): 1836-1846. https://doi.org/10.1007/ s11368-014-0966-5

Lykholat T., Lykholat 0. \& Antonyuk S. (2016). Immunohistochemical and biochemical analysis of mammary gland tumours of different age patients. Cytology and Genetics 50(1): 32-41. https://doi.org/10.3103/S0095452716010072

Lykholat Y.V., Khromykh N.A., Ivan'ko I.A., Matyukha V.L., Kravets S.S., Didur O.O., Alexeyeva A.A. \& Shupranova L.V. (2017). Assessment and prediction of the invasiveness of some alien plants in conditions of climate change in the steppe Dnieper region. Biosystems Diversity 25(1): 52-59. (In Ukrainian). https://doi.org/10.15421/011708

Mirzak O.V. (2001). The experience of studying the soils of large industrial centers of the steppe zone (for example, the city of Dnipropetrovsk). Gruntoznavstvo 1(1-2): 87-92. (In Ukrainian).

Morel J.L., Chenu C. \& Lorenz K. (2015). Ecosystem services provided by soils of urban, industrial, traffic, mining, and military areas (SUITMAs). Journal of Soils and Sediments 15(8): 16591666. https://doi.org/10.1007/s11368-014-0926-0

Mowbray T. \& Schlesinger W.H. (1988). The buffer capacity of organic soils of the Bluff Mountain Fen, North Carolina. Soil Science 146(2): 73-79. https://doi.org/10.1097/00010694198808000-00003
Murphy B. (2015). Key soil functional properties affected by soil organic matter - evidence from published literature. IOP Conference Series: Earth and Environmental Science 25: 012008. https://doi.org/10.1088/1755-1315/25/1/012008

Nelson P.N. \& Su N. (2010). Soil pH buffering capacity: a descriptive function and its application to some acidic tropical soils. Australian Journal of Soil Research 48(3): 201-207. https://doi. org/10.1071/SR09150

Novosyolova E.I., Volkova 0.0. \& Turyanova R. R. (2017). Soil enzymes as biodiagnostics indicator of heavy metal pollution of urbanozem. IOP Conference Series: Earth and Environmental Science 107: 012069. https://doi.org/10.1088/17551315/107/1/012069

Pavlović M., Pavlović D., Kostić O., Jarić S., Čakmak D., Pavlović P. \& Mitrović M. (2017). Evaluation of urban contamination with trace elements in city parks in Serbia using pine (Pinus nigra Arnold) needles, bark and urban topsoil. International Journal of Environmental Research 11(5-6): 625-639. https://doi. org/10.1007/s41742-017-0055-x

Raczuk J. \& Deska J. (2012). Buffer properties of forest soils in selected protected areas. Ecological Chemistry and Engineering. A 19(3): 231-237. doi: 10.2428/ecea.2012.19(03)024

Riley H., Pommeresche R., Eltun R., Hansen S. \& Korsaeth A. (2008). Soil structure, organic matter and earthworm activity in a comparison of cropping systems with contrasting tillage, rotations, fertilizer levels and manure use. Agriculture, Ecosystems \& Environment 124(3-4): 275-284. https://doi.org/10.1016/j. agee.2007.11.002

Schrader S. \& Zhang H. (1997). Earthworm casting: Stabilization or destabilization of soil structure? Soil Biology and Biochemistry 29(3-4): 469-475. https://doi.org/10.1016/S00380717(96)00103-4

Shipitalo M.J. \& Le Bayon R.-C. (2004). Quantifying the Effects of Earthworms on Soil Aggregation and Porosity. Earthworm Ecology, 2nd ed. In: Edwards, C. A (ed) Earthworm ecology. CRC Press, Boca Raton, pp 183-200. https://doi. org/10.1201/9781420039719.pt5

Sieghardt M., Mursch-Radlgruber E., Paoletti E., Couenberg E., Dimitrakopoulus A., Rego F., Hatzistathis A. \& Randrup T.B. (2005). The Abiotic Urban Environment: Impact of Urban Growing Conditions on Urban Vegetation. In: Konijnendijk C., Nilsson K., Randrup T., Schipperijn J. (eds) Urban Forests and Trees. Springer, Berlin, Heidelberg, pp 281-323. https://doi. org/10.1007/3-540-27684-X_12

Sjursen H., Michelsen A. \& Holmstrup M. (2005). Effects of freeze-thaw cycles on microarthropods and nutrient availability in a sub-Arctic soil. Applied Soil Ecology 28(1): 79-93. https:// doi.org/10.1016/j.apsoil.2004.06.003 
Smrž J. \& Norton R.A. (2004). Food selection and internal processing in Archegozetes longisetosus (Acari: Oribatida). Pedobiologia 48(2): 111-120. https://doi.org/10.1016/j.pedobi.2003.09.003

Stott D.E. \& Moebius-Clune B.N. (2017). Soil Health: Challenges and Opportunitie. In: Field D.J., Morgan C.L.S., McBratney A.B. (eds) Global Soil Security. Progress in Soil Science. Springer, Cham, pp 109-121. https://doi.org/10.1007/978-3-319-43394-3_10

Striganova B.R. (1980). Feeding of soil saprophages. Nauka, Moscow. 244 p. (In Russian).

Su Y.J., Wang Y.J., Zhang Y.L., Luo Y., Sun L., Song L. \& Liao W.Y. (2014). Soil pH buffer capacity of tea garden with different planting years. Ying Yong Sheng Tai Xue Bao 25(10): 2914-2918. (In Chinese).

Tomlin A.D., Shipitalo M.J., Edwards W.M. \& Protz R. (1995). Earthwormsand their influence on soil structure and infiltration. In: Hendrix, P. F. (Eds.). Earthworm ecology and biogeography in North America. Lewis Publishers Inc., Boca Raton, pp 159-183.

Toth Z., Hornung E., Baldi A. \& Kovacs-Hostyanszki A. (2016). Effects of set-aside management on soil macrodecomposers in Hungary. Applied soil ecology 99: 97-105. https://doi. org/10.1016/j.apsoil.2015.11.003
Truskavetskii R. S. (2003). Buffering capacity of soils and their main functions. Nove slovo, Kharkiv, 225p.

Tyrväinen L., Pauleit S., Seeland K. \& de Vries S. (2005). Benefits and Uses of Urban Forests and Trees. In: Konijnendijk C., Nilsson K., Randrup T., Schipperijn J. (eds). Urban Forests and Trees. Springer, Berlin, Heidelberg. pp 81-114. https://doi. org/10.1007/3-540-27684-X_5

Tyutyunnik Y.G. (2014). Genesis, diversity and ecology of urban soils (for example the park "Feofania", Kiev). Gruntoznavstvo 15(3-4): 65-73. (In Ukrainian).

van Rensburg H.G.J., Claassens A.S. \& Beukes D.J. (2009). Relationships between soil buffer capacity and selected soil properties in a resource-poor farming area in the Mpumalanga Province of South Africa. South African Journal of Plant and Soil 26(4): 237-243. https://doi.org/10.1080/02571862.2009.10639961

Zavaltseva O.A., Avanesyan N.M. \& Antonova J.A. (2014). Ecological and geochemical condition of soils of park territories of Ul'yanovsk under conditions of increasing anthropogenous loading. Contemporary Problems of Ecology 7(2): 250-260. https://doi.org/10.1134/S1995425514020176 